DOI: $10.30525 / 978-9934-588-61-7-39$

Yankovets T. M.

PhD in Economics, Associate Professor, Associate Professor at the Department of Marketing Kyiv National University of Trade and Economics

Vyshnevska M. $O$.

Senior Lecturer at the Department of Foreign Languages Kyiv National University of Technologies and Design

\title{
DIGITAL MARKETING: BACKGROUND, ESSENCE, MANAGEMENT
}

\section{Summary}

The backgrounds for digital marketing emergence and development have been discovered. The essential features of the "digital marketing» concept have been identified and their close relationship has been established, allowing to formulate our own definition of digital marketing, which clearly defines its intangible and financial goals for brands. The principles of digital marketing have been formulated. The components of digital marketing have been systematized and described: technologies, channels, methods, tools. The advantages of digital marketing in modern conditions have been revealed. Digital marketing management based on the principles of strategic approach has been substantiated. The definition of digital marketing strategy has been formulated and the stages of its formation and implementation have been formed. The particular attention has been paid to the selection and distribution of digital tools of consumer promotion according to the stages of the consumer's path to select the most effective ones in order to form a longterm partnership.

\section{Introduction}

The rapid development of digital technologies under the influence of technological, psychological and social factors has led to changes in people's behavior and, consequently, in the business models of modern companies. Such transformations lead to the need to use strategies, technologies, methods, tools of digital marketing. A study of Global Center for Digital Business Transformation notes that «in the next 5 years, the digital revolution will displace $40 \%$ of companies that are now leaders in the industry unless they make the digital transformation» [1]. It is the digital transformation of business and marketing that ultimately reduces the cost of money and time, both for companies and consumers, which leads to increased value of goods in the minds of consumers and, consequently, to the increase of sales, profitability, capital and value of companies.

Transformation of marketing from traditional to digital one, influenced by digital technology, is a natural process. The essence of marketing and 
methodology has not changed. As before, its main task is to focus on the customers taking into account their human qualities, values, behavior, which allows companies to use classic marketing tools (4Ps: product, price, place, promotion) to sell their product the best way and get economic benefits. The marketing opportunities of companies have changed towards expansion, due to the using digital capabilities of the Internet and mobile technologies.

\section{Part 1. The background, essence and the components of digital marketing}

The development of the fourth technological system branches based on the development of electronics, organic chemistry and means of communication led to the emergence of computers and software products for them in the 1950s. Leading scientific and military laboratories of the United States, Great Britain and France independently developed the concepts of the global computer network.

In the early 60s of the 20th century an American engineer and inventor Paul Baran, working for the RAND, a nonprofit organization that served as a strategic research center and performed the U.S. government and military contracts as well as related organizations, invented and described a method of splitting information into separate packets, i.e., «message blocks». Digitally, they quickly move by the network through available channels, independently of each other, and are collected at the end point. Later, developing the ideas of Paul Baran, the scientist of the National Physical Laboratory of England Donald Davis, who worked on a similar architecture at the same time, called this distribution and collection of information packet switching [2]. The purpose of the research conducted by Paul Baran during the Cold War between the United States and the Soviet Union was to prevent the information leakage in case its interception due to the inability to collect it from separate «message blocks». In addition, this method ensured the delivery of data to the destination even in case of loss (for example, during a nuclear bombing) or non-use for various reasons of one or more blocks, provided that the network is maintained.

The architectural principle, developed by Paul Baran and used as a basis on the modern Internet, was first used in the ARPANET computer network, commissioned by the US Department of Defenses Advanced Research Projects Agency (DARPA) in 1969, as a reliable computer system of information transfer and communication in the conditions of nuclear war and disorganization $[3 ; 4$, p. 5]. Researchers from the best research and technical centers in the country - the University of California, Los Angeles, Stanford University, the University of Utah and the University of California, Santa Barbara - worked on the technical implementation of this project. The test task of transmitting information using the latest method of communication was performed successfully at the second attempt. The experiment was conducted on October 29, 1969 [2].

Initially, the ARPANET network was closed and connected only the computers of military laboratories and a few US research centers. Later, with 
the rise in popularity and the emergence of the first e-mail program in 1971, more and more Pentagon-licensed organizations joined the ARPANET. In 1973, the network became international. Organizations from the United Kingdom and Norway were connected to it via a transatlantic telephone cable.

During the 1970s, ARPANET was mostly used to send e-mails and could not easily interact with other emerging networks due to non-compliance with technical standards. At the end of the decade, data transmission protocols based on the development of packet switching development by Donald Davis began to appear, they were standardized in 1982-1983. This allowed the American researcher Jon Postel to transfer ARPANET from NCP to TCP/IP. In the same year, the name «Internet» appeared for the first time, which became synonymous with ARPANET. A year later, a domain name system was developed and is still in use today.

In 1984, the US National Science Foundation (NSF) created the interuniversity network NSFNet consisted of smaller networks and had much higher bandwidth than the ARPANET. Over time, NSFNet has transformed into the modern Internet, which has been available to the public since 1991. ARPANET ended its existence in 1990 as the unpromising one.

Internet marketing first appeared in the early 1990s, when text sites on the Internet began to post information about products [5, p. 214]. With the advent and development of mobile technology in the first half of the 2000s, digital marketing began to develop rapidly.

According to the results of the analysis of digital marketing concept researches in sources [6-10], its essential features have been revealed (Figure 1).

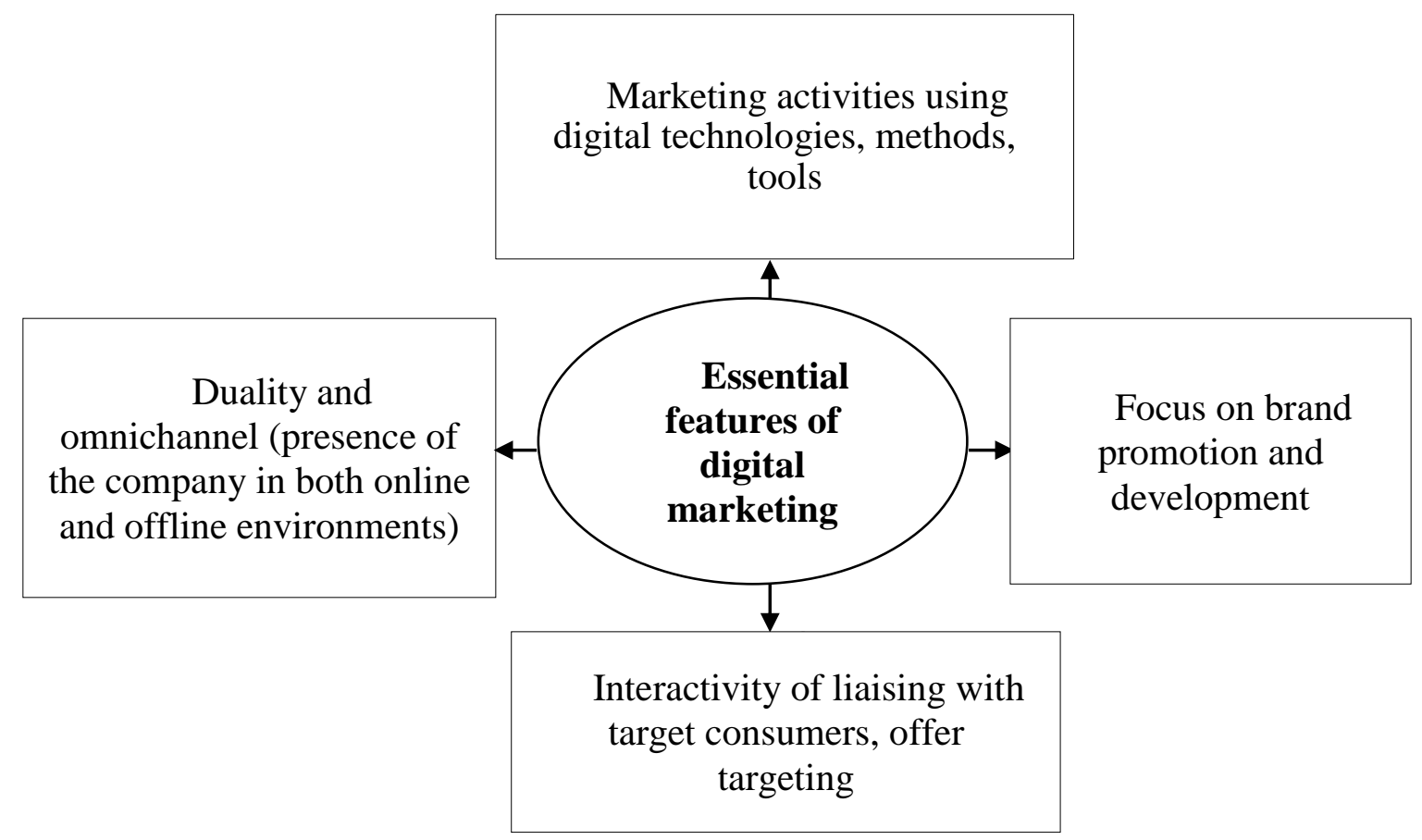

Figure 1. Essential features of the «digital marketing» concept

Source: developed by the authors 
All these features of digital marketing are closely related. Thus, duality and omnichannel allow us to hide the boundaries between online and offline from the consumer, which makes his transition from one environment to another insensible and painless. This is facilitated by the development of effective verbal and visual brand identifiers, which allow consumers to obtain unique and relevant values. This means that digital marketing will be the most effective for companies that build and develop their own brands. Also, digital technologies, methods and tools allow you to form the consumer experience through interactivity, which attracts the consumer to the relationship with the brand and gently leads through the sales funnel without losing the customer after the purchase. And gathering information about consumers using BigData technology, artificial intelligence and machine learning allows to segment consumers and form targeted proposals taking into account the identified interests and purchasing behavior.

Considering the identified essential concept features, digital marketing means marketing activities of the enterprise using digital technologies, channels, methods, tools, which allows to develop targeted proposals to increase capital and strength brand, sales, profits, profitability and brand value due to the presence of both online and offline environments and interactive cooperation with consumers. This definition, in contrast to the existing ones, clearly defines the intangible and financial goals of digital marketing for brands, which are possible in compliance with the principles of digital marketing [11, p. 24]:

- human-oriented - a person with the feelings and benefits that he or she gives to any things should be on the first place. Today, in the face of tight competition in the world of brands, consumers are not just people who buy goods but partners with their own attitude to the product, who take part in the management process together with companies;

- systematicity - the speed of change and a large array of information in the area of digital-marketing, which needs to be constantly monitored by current trends in digital technology;

- innovativeness - all marketing activities based on the use of modern digital technologies should be aimed at increasing competitiveness and, accordingly, the product value for consumers;

- mobility and communicativeness - the rapid introduction of the latest communication and sales channels in marketing activities based on the most widely used consumers of modern technical devices;

- omnichannel - the use of all online and offline channels of communication and sales as the only mechanism to facilitate consumer perception based on common rules for all channels;

- informativeness - sales growth is provided by high-quality content. Content marketing remains the most powerful digital instrument in the field of digital marketing [12]. Qualitative content should meet the following requirements: to generate large traffic; to represent the company as an expert, 
which brings the user to the opinion that company product is necessary for him or her; to sell [13, p. 14];

- automation and individualization - using BigData technologies and methods, artificial intelligence, machine learning that allows to process huge amounts of information and, based on the results of analysis, to develop accurate forecasts of consumer behavior, to formulate personalized offers for each particular customer, which contributes to the increase of value and sales, profits, financial results of enterprises;

- profitability - justification of marketing strategies and measures, using innovative digital technology and related tools aimed at increasing the value of the product for consumers, ensures meeting the primary goal of innovationoriented enterprises - increase in sales, profitability, capital and brand value.

Digital marketing technologies are generally divided into Internet technologies, telephony and mobile technologies:

- Internet technologies include sites, blogs, social networks, search engines, banner advertising, contextual advertising and more;

- Telephony includes the use of dialer numbers, greetings, answering machine, on hold sounds (music, messages), call forwarding;

- Mobile technologies include mobile communications, mobile advertising, mobile sites and mobile applications.

For the moment, the main channels of digital marketing include [7, p. 297; 8, p. 369]:

1. Internet and Internet access devices (computers, laptops, tablets, smartphones).

2. Mobile devices, which are portable. In essence, a mobile device was any small device that usually contains a display and a mini keyboard. Later, a touch screen with a virtual keyboard appeared. Modern mobile devices include smartphones, tablets, e-books, phones, netbooks.

3. Local area networks (Intranet, Extranet). An intranet is an internal corporate network of an enterprise that uses Internet technologies and services (e-mail, web-sites, etc.). The intranet connects to external networks, while working autonomously; it is not accessible from the outside, because it is a private corporate network. Extranet is a corporate network protected from unauthorized access, which uses Internet technologies for internal corporate purposes, as well as to provide some corporate information to business partners of the enterprise. As the extranet provides access to the outside, there is higher level of data protection than in the intranet.

4. Digital television, in which the transmission, processing and television signal storage is in digital form. In addition to television broadcasting systems, digital television methods and tools are the basis of modern video communication systems, which include video conferencing and telepresence.

5. Interactive screens (such as touchpads and large screens in retail chains) are essentially large gadgets with a built-in processor and software.

6. POS-terminals are modern software and hardware systems for trading transactions using payment cards and other contactless devices. 
7. Digital gadgets are devices that can collect and transmit information (they are becoming a more and more significant part of people's lives. Previously, they have used to control only physical activity; today, they can measure heart rate, blood pressure, blood sugar and increasingly monitor health by synchronizing with mobile devices).

An enterprise that uses digital marketing technologies and channels must keep in mind the need for brand development and omnichannel.

In addition, the innovative technologies of BigData, predictive analytics, artificial intelligence and machine learning, virtual and augmented reality, and others have been actively used in digital marketing today.

BigData technologies and techniques in digital marketing with the use of predictive analytics of artificial intelligence and machine learning allow enterprises to conduct global marketing companies tailored to specific target customers, taking into account their individuality, and accordingly develop personalized proposals that directly affect sales, profits, capital, brand value.

The advantages of artificial intelligence in digital marketing are classified [11, p. 24-25]:

- complete client base review and segmentation based on the identified values of consumers; assessment of marketing activities for each target group, identification of possible losses of the most valuable consumers; development of effective marketing strategies based on accurate forecasting of consumer behavior, which helps to increase sales and improve financial results;

- the ability to link sales reports, marketing companies, the emergence of new online tools, applications or social networks that potentially can contain new data on target customers, which will help to determine their value for the company;

- collection of a huge amount of data on customers and potential consumers (leads) from both external and internal sources, which makes it possible, due to the powerful algorithm of analysis, to arrange the leads in order to reduce the likelihood of their conversion, that is, transformation into customers, and develop appropriate strategies that will reveal their value;

- summarizing information on the range and clients and proposing specific assortment positions for specific consumers, taking into account their individual needs and values, which allows to increase sales volumes and optimize costs;

- the possibility of developing an optimal marketing strategy for customer retention based on data collection by artificial intelligence and the generation of valuable information through the machine learning technology.

Over the past 20 years, digital transformation has gone from organic search, then paid search, through the development of social networks to the rapid growth of worldwide mobile devices use (especially smartphones). Mobile phones today have become the world's most popular device for viewing web pages (51.4\% with an annual increase of 25\%). Computers and laptops are used less (annual decline is 19\%), although they continue to occupy a significant place in use (43.4\%). Tablets are less used (4.9\% with an 
annual decrease of $6 \%$ ). The use of other devices has increased by $30 \%$ per year, but their share is the least $(0.13 \%)$ [14].

For businesses, in the light of growing smartphones use, the prospect of developing and/or implementing mobile applications for expanding markets, increasing sales volumes and, consequently, financial results, of brand value, is also growing.

For the successful use of digital marketing technologies applying the omnichannel, it is important to combine the following methods [15, p. 94]:

- online communications (search engine marketing, social media marketing, online advertising, email marketing, partnerships with other sites and others);

- traditional media (press, television, direct mail and others).

Thus, integrated marketing communications are formed, which takes into account the interaction with the client throughout his or her life cycle.

Table 1

\section{Advantages of digital marketing compared to traditional and Internet marketing}

\begin{tabular}{|l|c|c|c|}
\hline Parameters & $\begin{array}{l}\text { Traditional } \\
\text { marketing } \\
\text { the } 20^{\text {th }} \\
\text { century }\end{array}$ & $\begin{array}{c}\text { Internet } \\
\text { marketing }\end{array}$ & $\begin{array}{c}\text { Digital } \\
\text { marketing }\end{array}$ \\
\hline Stages of marketing development & + & + & $\begin{array}{c}2003- \\
\text { present }\end{array}$ \\
\hline $\begin{array}{l}\text { Focus on the target consumer, taking into } \\
\text { account human feelings and values }\end{array}$ & - & + & + \\
\hline $\begin{array}{l}\text { Orientation of messages from the } \\
\text { producer to the specified consumer } \\
\text { considering consumer behavior, } \\
\text { personalization of the offer }\end{array}$ & - & + & + \\
$\begin{array}{l}\text { Convenience and speed of the process of } \\
\text { choosing a product or service for the } \\
\text { consumer }\end{array}$ & - & + & + \\
\hline $\begin{array}{l}\text { High level and speed of reaction to } \\
\text { changes in the consumer behavior }\end{array}$ & - & - & + \\
\hline $\begin{array}{l}\text { Ability to apply the concept of } \\
\text { omnichannel in communication and sales }\end{array}$ & - & + & + \\
\hline Web-analytics capacities & - & - & + \\
\hline Mobile analytics capacities & & & + \\
\hline
\end{tabular}

Source: developed by the authors

Each method of digital marketing has its own tools that are important for success. Content marketing (20\%) remains the leader among digital marketing tools in recent years [12]. The second best is Big Data, including market and customer understanding, as well as predictive analytics (14\%), the artificial intelligence and machine learning are the third (about 14\%). Social media marketing (10\%), mobile marketing including mobile advertising, site and application development (9\%), marketing automation, including CRM, 
behavioral e-mail marketing and web personalization (9\%), conversion rate optimization/site improvement (5\%), search engine optimization (4\%) are also used. The use of other digital marketing tools in the overall structure takes from $3 \%$ and below.

Taking into account the above-described essence and components of digital marketing, the comparison of traditional, Internet and digital marketing is shown in Table 1 in order to identify the benefits of the latter in modern conditions.

For the successful use of technologies, channels, methods and tools of digital marketing, it is important to manage this activity.

\section{Part 2. Digital marketing management based on a strategic approach}

The emergence and constant updating of a large number of digital marketing tools require some systematization in order to make the right choice for timely delivery of the necessary information about the product and/or company in order to save time and money of both companies and consumers. At the same time, the user experience improvement provided by companies through the right means of communication and sales, of course, directly affects the improvement of financial performance and value of companies.

Today, marketing theorists and practitioners agree on the need for a strategic approach to digital marketing management as a defining direction of doing business in the current market conditions. However, not all companies today use this approach in their work. Being aware of the need to use a digital marketing strategy to grow a business and build a strong brand, many companies face challenges during its development and implementation. These include $[12 ; 16]$ : lack of strategic approach; lack of clear goals and, accordingly, a digital marketing plan; misunderstanding of the online market due to lack of research on consumer demand and underestimation of customer needs for online services; lack of a strong online offer; insufficient knowledge of their online customers; lack of digital media integration with traditional ones; lack of budget allocated for digital marketing; lack or insufficiency of digital skills; duplication of digital marketing functions; lack of flexibility and dynamism in the use of new approaches in business and marketing; lack of reaction to the results of analytics.

Nowadays, there is no clear and generally accepted definition of digital marketing strategy due to differences in the directions and aspects of research in the scientific world, as well as differences in the enterprise management. At the same time, there are common features inherent in all strategies used in various life spheres, including business. In general, any strategy is a program (plan) to achieve long-term goals and includes the following elements: goals, resources, indicators, measures, monitoring. The formation and implementation of the strategy involves the management of this process, which is performed by the classic functions: planning, organization, motivation, control and regulation, to which we add the function of analysis. Using modern digital technologies and BigData methods, artificial 
intelligence and machine learning, the analysis opens up great opportunities for digital marketing in forecasting, creating value and targeted proposals and, ultimately, increases the value of companies. Implementation of digital marketing management functions on the strategic approach basis involves the following:

- analysis is necessary to identify the best experience of competitors as well as untapped opportunities, which allows the brand to differentiate and find its uniqueness;

- planning involves setting goals and defining all resources, methods and means of their implementation, as well as KPI justification and their planned values, which is reflected in the documented system of plans;

- organization is important from the point of view of effective organizational structure formation and selection of the necessary number of correspondingly qualified workers to perform the planned tasks;

- motivation involves the formation of an incentive system (tangible and intangible), taking into account the internal motives of employees to better perform their tasks and achieve the relevant goals;

- control involves assessing the KPI by comparing their actual values with the planned and identifying possible deviations, as well as identifying the causes of deviations;

- regulation is used to eliminate the causes of negative deviations of actual KPI values from the planned ones, plans adjustment, mediating conflicts between employees in the working process, i.e., real-time corrective action to effectively (timely and within budget) implement the plans.

The use of digital technologies, channels, methods, tools of digital marketing in order to increase the value of companies involves their integration into the marketing strategy. In addition, all marketing decisions in modern conditions involve the use of innovation and coordination with financial decisions. Based on these considerations, it is proposed to understand the digital marketing strategy as a system program of actions (measures) with the use of innovative digital technologies, channels, methods, tools to achieve the digital marketing goals.

The development of digital marketing strategy can be conveniently divided into two stages: formation and implementation.

At the formation stage, the management functions of analysis, planning and organization are implemented by performing the following actions:

1. Setting digital marketing goals, which must be coordinated with business goals, in accordance with the requirements for goal setting according to the SMART methodology.

In general, the strategic goals of digital marketing, as well as business goals, are grouped into two areas:

- improving the brand image (increasing brand awareness; increasing brand strength and brand capital; increasing consumer loyalty and forming a community of «brand lawyers»); 
- increasing sales volume (attracting potential customers; making agreements; related products sales; sales increase; affiliate programs). It is important to coordinate sales and communication channels, taking into account omnichannel.

According to the defined strategic goals, the tactical goals are formed, and their implementation ensures the implementation of strategic goals. Tactical goals of digital marketing include: increasing the number of leads; increasing the number of regular customers; increasing the degree of satisfaction with the product; increasing product loyalty and others.

2. The ground for key performance indicators (KPI). Each goal, according to the requirements for goal formulation considering the SMART method, should be quantified for the ability to assess its achievement in a timely manner, which necessitates the choice of KPI.

Indicators for assessing the digital marketing strategic goals can be general business indicators adopted to assess its effectiveness.

Forming the companies relations with their consumers, the consumer path (Customer Journey) remains relevant, which, from the viewpoint of the company and its actions in relation to consumer, is called differently (sales funnel, sales tunnel, marketing spiral, hourglass). For a long time, companies conducted the consumer on his or her way according to the classic AIDA model, i.e., brought to the moment of purchase and stopped there. Today, when building long-term partnerships, under the conditions of fierce competition in the digital marketing field, to leave the consumer after the purchase is unacceptable. After the purchase stage, a new stage begins - the formation of loyalty. One of the modern models of the consumer path, which takes into account loyalty, consists of stages: See, Think, Do, Care. In this model, the See stage includes the first two stages of the AIDA model. Indicators for estimating the tactical goals of digital marketing are aimed at assessment, first of all, of content quality, through which the relationships of the brand with consumer are built. These indicators are distributed by the consumer path stages [6, p. 166; 17]:

- brand visibility indicators (Awareness, Attention, See) measure the coverage and brand awareness: number of impressions (how many times the content has been shown); uniqueness of users (how many people actually have viewed the content); brand recognition (percentage of people who can remember the brand name);

- interest indicators (Interest, See) measure the interest in brand content: the number of views by each user (the number of pages visited by each user on the brand's website); bounce rate (percentage of people who leave the site after visiting one page (Google considers the refusal as not going to another page [18]; Yandex considers leaving the site within the first 10 seconds as a refusal [19]); time of visiting site (site visit duration);

- indicators of search accessibility (Desire, Think) measure how to find content using search engines: positions in search engines (when issued for certain key queries); links in search engines (the number of users who go (or 
the percentage of conversions) to the site, based on the results of search engines);

- performance indicators (Action, Do) - measure how effective the content is in terms of bringing users to the implementation of the company's planned action: clickthrough rate; conversion factors (percentage of users who perform the expected actions: registration, filling out the contact form; purchases);

- loyalty indicators (Care) measure how much the users are willing to share content on social networks: the exchange rate (the number of «share» correlation to the total number of content display); involvement rate.

3. The external environment analysis, which includes market and market trends analysis in its own and related niches; consumer analysis; analysis of competitors.

Under the conditions of fierce competition in the digital marketing field, the analysis of competitors is particularly important. It is conducted to obtain the necessary information to identify strengths and weaknesses of competitors, form an idea of their goals, strategies and opportunities to improve their effectiveness. According to the results of this analysis, it is possible to obtain data on traffic channels, digital metrics (traffic, rejections, conversions, etc.), marketing messages and advertising budgets of competitors, and so on. Today, a large number of services are available for such analysis, which helps to identify competitors based on the common key user queries and analyze them by various parameters.

4. Analysis of the company's internal digital capabilities in the basic areas of marketing (4Ps: product, price, place, promotion).

5. Rationale for the choice of digital technologies, channels, methods, tools, in accordance with the above principles of digital marketing.

At the stage of the digital marketing strategy implementation, the management functions such as organization, motivation, control and regulation are implemented by performing the following actions:

6. Development of digital marketing specific measures, including setting deadlines, choosing digital marketing tools for promotion, creativity, budget calculation, choosing people responsible for implementation, the distribution of responsibilities.

Table 2 presents digital marketing tools, distributed according to the consumer status and the stages of his or her path, to select the most effective ones for the consumer promotion and building long-term partnerships with companies.

The determinative and most used tool today in forming the long-term partnerships with the consumer is the content that is present in almost all digital tools for promotion and sales. On the one hand, the content should reduce the fears and pains of consumers, as well as help to fulfill their desires, i.e., represent value for consumers. On the other hand, the content should contain stories that reflect the brand values, its individuality and character. By analogy with a product that is developed only after the need has been identified to meet and solve consumer problems, the content is developed to combine consumer fears 
and desires with brand stories that will help to eliminate or reduce those fears and fulfill desires. Hence it is possible to conclude that constant work and deep knowledge of the target audience are important.

In general, the content can be presented in different formats:

- written as press releases, articles, e-mails, analytical reports, cases, books, etc.;

- visual as infographics, comics, interactive graphics, presentations, games, videos, short and feature films, etc.

7. Implementation of digital marketing measures.

8. Evaluation of digital marketing strategy effectiveness is carried out using KPI, justified at the stage of formation.

9. Improving digital marketing strategy. The great advantage of digital marketing is the ability to accurately calculate all key indicators using web and mobile analytics, track performance by campaign names, content topics, creatives, distribution channels, which greatly simplifies control and facilitates rapid response and adjustment. Also, the availability of real-time evaluation indicators allows you to conduct A/B testing and choose the most effective digital marketing tools.

Table 2

\section{Digital tools of consumer promotion}

\begin{tabular}{|c|c|c|c|}
\hline $\begin{array}{l}\text { Consumer } \\
\text { status }\end{array}$ & \multicolumn{2}{|c|}{ Customer Journey } & Digital tools \\
\hline \multirow{2}{*}{$\begin{array}{l}\text { Cold } \\
\text { potential } \\
\text { consumer }\end{array}$} & \multirow{2}{*}{$\begin{array}{c}\text { See } \\
\text { (interest) }\end{array}$} & Awareness & $\begin{array}{l}\text { Advertising (Google Ads - contextual } \\
\text { advertising), advertising on social networks } \\
\text { (Facebook/Instagram Ads), MediaAds (media } \\
\text { advertising), search marketing, radio, TV, } \\
\text { boards, brochures }\end{array}$ \\
\hline & & $\begin{array}{l}\text { Increasing } \\
\text { involvement }\end{array}$ & $\begin{array}{l}\text { Messages (posts) in blogs, podcasts, online } \\
\text { videos, Facebook/Instagram Ads + content, } \\
\text { Google Ads, forums (comments, messages), } \\
\text { site (useful content) }\end{array}$ \\
\hline \multirow{3}{*}{ Lead } & \multirow{3}{*}{$\begin{array}{l}\text { Think } \\
\text { (intention) }\end{array}$} & $\begin{array}{l}\text { Subscribers } \\
\text { engagement }\end{array}$ & $\begin{array}{l}\text { Establishing contacts on social networks, online } \\
\text { subscriptions, registration for webinars, email- } \\
\text { subscription }\end{array}$ \\
\hline & & $\begin{array}{l}\text { Conversion } \\
\text { increase }\end{array}$ & $\begin{array}{l}\text { Offering inexpensive goods, services, webinars, } \\
\text { product demonstration }\end{array}$ \\
\hline & & $\begin{array}{l}\text { Enthusiasm } \\
\text { awakening }\end{array}$ & $\begin{array}{l}\text { Consumer onboarding, Facebook/Instagram } \\
\text { (comments, personal messages) }\end{array}$ \\
\hline \multirow[b]{2}{*}{ Consumer } & \multirow[b]{2}{*}{$\begin{array}{c}\text { Do } \\
\text { (decision) }\end{array}$} & $\begin{array}{l}\text { Making a } \\
\text { purchase }\end{array}$ & Selling key offers, CRM system, Call Tracking \\
\hline & & $\begin{array}{l}\text { Repeat } \\
\text { purchase }\end{array}$ & $\begin{array}{l}\text { Remarketing (offering related goods, } \\
\text { promotions), abandoned basket, mailings } \\
\text { according to the database (with personal offers) }\end{array}$ \\
\hline $\begin{array}{l}\text { Loyal } \\
\text { consumer } \\
\text { (regular } \\
\text { customer) }\end{array}$ & $\begin{array}{c}\text { Care } \\
\text { (loyalty) }\end{array}$ & $\begin{array}{l}\text { Creating } \\
\text { brand } \\
\text { defenders }\end{array}$ & $\begin{array}{l}\text { Wow-effect, positive feedback from satisfied } \\
\text { consumers, maintaining product value, prompt } \\
\text { service, gift marketing }\end{array}$ \\
\hline
\end{tabular}

Source: developed by the authors 


\section{Conclusions}

The rapid changes in the external environment due to the development of digital technologies have a significant impact on consumer behavior and, consequently, the digital transformation of business and marketing. The emergence and development of the Internet and mobile technology, BigData technology, artificial intelligence, machine learning, virtual and augmented reality and other technologies have helped to transform marketing from traditional through Internet marketing to digital marketing, which has become significantly widespread since 2010 .

The essential features of digital marketing are: retention of methodology when using the latest digital technologies, channels, methods, tools; duality and omnichannel; interaction of target consumer engagement, offer targeting; focus on brand development. Identification of essential features allowed to formulate our own definition of digital marketing, which means marketing activities of the enterprise using digital technologies, channels, methods, tools, which allow to develop targeted proposals to increase capital and brand strengths, sales, profits, profitability and brand value enhancement due to the presence of both online and offline environments and interactive consumer engagement. This definition, in contrast to the existing ones, clearly defines the intangible and financial goals of digital marketing for brands, which can be achieved by following the principles of digital marketing formulated by the authors: human orientation, consistency, innovation, mobility and communication, omnichannel, information, automation and individualization, profitability.

For the successful use of the technologies, channels, methods and tools of digital marketing described in the research, it is important to manage it on the basis of a strategic approach.

Considering common features intrinsic to the strategies used in various spheres of life, including business, as well as the view that marketing decisions in modern conditions involve the use of innovation and coordination with financial decisions, it is proposed to understand the digital marketing strategy as a systematic program of actions (measures) with the use of innovative digital technologies, channels, methods and tools to achieve the goals of digital marketing.

The development of digital marketing strategy is proposed to be divided into two stages: formation and implementation.

When forming the specified strategy, the management functions of analysis, planning and organization are realized by the effect of such actions: setting the digital marketing goals; substantiating key performance indicators (KPI); analyzing the external environment; analyzing the company's internal digital capabilities; substantiating the choice of digital technologies, channels, methods, tools.

At the stage of the digital marketing strategy implementation, the management functions of organization, motivation, control and regulation are implemented by performing the following actions: developing the specific measures of digital marketing; implementing digital marketing measures; 
evaluating the effectiveness of digital marketing strategy; improving digital marketing strategy.

The study pays special attention to the selection and distribution of digital tools of consumer promotion in phases of consumer path to help companies choosing the most effective ones in order to form a long-term partnership with the consumer.

\section{References:}

1. Kotvycjkyj I. (2018) Cyfrova ekonomika - majbutnje vzhe zaraz [The digital economy is the future now]. Glavnoe. Novosti. Analatika [The main thing. News. Analytics]. Available at: https://glavnoe.ua/articles/a12171-cifrova-ekonomika-\%E2\%80\% 93-majbutne-vzhe-zaraz (accessed 30 May 2020).

2. Pol Beran. Grodno by online (2020) Available at: http://www.grodno.by/grodno/ history/biblio/paul_baran.html (accessed 20 May 2020).

3. Istoriya Interneta. Wikipedia. (2020) Available at: https://ru.wikipedia.org/wiki/ История_Интернета (accessed 22 Мау 2020).

4. Lytovchenko I. L., Pylypchuk V. P. (2008) Internet-marketyngh [Internet marketing]. Kyiv: Center for Educational Literature. (in Ukrainian)

5. Shpylyk S. (2015) Internet jak efektyvnyj marketynghovyj instrument suchasnogho pidpryjemstva [The Internet as an effective marketing tool of a modern enterprise]. Galician Economic Bulletin, vol. 2, no. 49, pp. 212-223.

6. Filip Kotler, Khermavan Kartadzhaya, Ayven Setiavan. (2020) Marketing 4.0. Razvorot ot traditsionnogo $k$ tsifrovomu: tekhnologii prodvizheniya $v$ Internete [Marketing 4.0. Traditional to Digital U-Turn: Internet Promotion Technologies]. Kyiv: «KM-BUKS». (in Russian)

7. Marchuk O. O. (2018) Cyfrovyj marketyngh jak innovacijnyj instrument upravlinnja [Digital marketing as an innovative management tool]. Economy and society, no 17, pp. 296-299.

8. Oklander M. A., Romanenko O. O. (2015) Specyfichni vidminnosti cyfrovogho marketynghu vid internet-marketynghu [Specific differences between digital marketing and Internet marketing]. Economic Bulletin of NTUU «KPI», no. 12, pp. 362-371.

9. Romat E. (2016). Ponyatie tsifrovogo (DIGITAL) marketinga i ego osnovnye kharakteristiki [The concept of digital (DIGITAL) marketing and its main characteristics]. Marketing and advertising, no 7-8, pp. 21-27.

10. Oklander M. A. (2017) Cyfrovyj marketyngh - modelj marketynghu XXI storichchja [Digital marketing is a marketing model of the 21st century]. Odessa: Astroprint. (in Ukrainian)

11. Yankovets T., Vyshnevska M. (2019) Innovations and digital marketing: current trends of development. European Journal of Economics and Management, vol. 5, no 4, pp. 21-27. (in English)

12. Smart Insights (2019) Oficijnyj sajt kompaniji [Homepage Smart Insights]. Available at: https://www.smartinsights.com/ (accessed 25 April 2020).

13. Kryukova E. Savel'ev D. (2018) 100+ khakov dlya internet-marketologov: Kak poluchit' trafik $i$ konvertirovat' ego v prodazhi [100+ Hacks for Internet Marketers: How to Get Traffic and Convert It to Sales]. Moscow: Alpina Publisher. (in Russian)

14. KANTAR v Ukrajini [KANTAR in Ukraine] (2019) Oficijnyj sajt kompaniji [Homepage KANTAR in Ukraine]. Available at: https://tns-ua.com/ (accessed 12 April 2020).

15. Jankovecj T. M. (2019) Cyfrovi tekhnologhiji pidvyshhennja vartosti brendiv [Digital technologies to increase the value of brands]. Bulletin of KNETU, vol. 4, no. 126, pp. 85-100. 
16. Dave Chaffey. (2020) 10 reasons you need a digital marketing strategy in 2020. Smart Insights. Available at: https://www.smartinsights.com/digital-marketing-strategy/ digital-strategy-development/10-reasons-for-digital-marketing-strategy/ (accessed 4 May 2020).

17. ERday, ERpost, ERview (2020) FeedSpy. Available at: https://feedspy.net/blog/ view/id/10 (accessed 15 April 2020).

18. Printsipy raboty algoritmov Google Poiska [The principles of operation of Google search algorithms]. (2020) Google search. Available at: https://www.google.com/intl/ru/ search/howsearchworks/algorithms/ (accessed 25 May 2020).

19. Vse algoritmy poiskovoy sistemy Yandeks po godam [All Yandex search engine algorithms by years]. (2020) Pixel Plus. Available at: https://pixelplus.ru/samostoyatelno/ stati/prodvizhenie-saytov/algoritmy-ranzhirovaniya-yandex.html (accessed 29 May 2020). 